This item was submitted to Loughborough's Research Repository by the author.

Items in Figshare are protected by copyright, with all rights reserved, unless otherwise indicated.

\title{
Flemish Diamond or ABC-Axis? The spatial structure of the Belgian metropolitan area
}

PLEASE CITE THE PUBLISHED VERSION

https://doi.org/10.1080/09654313.2016.1139058

\section{PUBLISHER}

(c) Taylor \& Francis

\section{VERSION}

SMUR (Submitted Manuscript Under Review)

\section{PUBLISHER STATEMENT}

This work is made available according to the conditions of the Creative Commons Attribution-NonCommercialNoDerivatives 4.0 International (CC BY-NC-ND 4.0) licence. Full details of this licence are available at: https://creativecommons.org/licenses/by-nc-nd/4.0/

\section{LICENCE}

CC BY-NC-ND 4.0

\section{REPOSITORY RECORD}

Van Meeteren, Michiel, Kobe Boussauw, Ben Derudder, and Frank Witlox. 2019. "Flemish Diamond or Abcaxis? the Spatial Structure of the Belgian Metropolitan Area". figshare. https://hdl.handle.net/2134/35346. 


\title{
Flemish Diamond or ABC-Axis? The spatial structure of the Belgian metropolitan area
}

\author{
An abridged version of this chapter is published as: \\ Van Meeteren M, Boussauw K, Derudder B and Witlox F (2016) Flemish Diamond or \\ ABC-Axis? The spatial structure of the Belgian metropolitan area. European Planning \\ Studies. DOI:/10.1080/09654313.2016.1139058
}

Please refer to the published version.

\begin{abstract}
This contribution traces the evolution of the Belgian urban system by adopting an historical taxonomy of agglomeration-economy regimes, and poses the question whether a new centralizing agglomeration-economy regime based on renewed 'metropolization' can be observed. Belgium has federalized into three regions during the last decades, and different spatial perspectives emerged about how the central metropolitan area crosscuts the regional borders. After placing Belgian metropolization in its historical context, we engage with its contemporary geography. We inquire if the metropolitan core of Belgium is more akin to the 'Flemish Diamond', with capital city Brussels as the southernmost node, or whether a spatial pattern reminiscent of the historical 'Antwerp-BrusselsCharleroi (ABC)-Axis' is a more adequate description. To answer these questions, we examine the spatial integration of the Belgian labor market utilizing Vasanen's (2012) connectivity field method and a 2010 nation-wide travel-to-work dataset. The results indicate that contemporary metropolization in Belgium can be topographically expressed as an area that is more trans-regional than the Flemish Diamond yet more polycentric than an extension of Brussels, thus pointing to renewed economic centralization tendencies at the supra-regional level.
\end{abstract}




\subsection{Introduction}

Although cities and 'the urban' are considered paramount to present-day economic growth, there is far less agreement on how the contemporary city and particularly its borders should be defined (McCann and Acs, 2011; Dijkstra et al., 2013). Even if we straightforwardly adopt the urban economics perspective that cities exist because of agglomeration economies (Rosenthal and Strange, 2004), it turns out that agglomeration economies consist of different social processes that have different spatial-economic effects and reach (Phelps, 2004). Agglomeration economies accruing from labor markets will define a different city scale than an urban region defined by inter-firm linkages or a settlement system derived from the geography of amenities (van Meeteren et al., [Chapters 2-3]). Moreover, the types and geographical scales of agglomeration economies that manifest themselves at particular segments of time-space depend on sociological and technological contexts, as well as on the position of an urban region in the international division of labour (Cox, 2002; Sassen, 2008): different eras, due to different technologies, economies and mobilities, have produced spatially variegated geographies (Phelps and Ozawa, 2003). Henceforth, we will call these spatial-temporal fixes (Jessop and Oosterlynck, 2008) 'agglomeration-economy regimes'.

In the ongoing debate concerning the geography of knowledge-intensive economic development and the cognitive-cultural economy (Scott, 2012), a new agglomerationeconomy regime referred to as 'metropolization' has recently been identified (Krätke, 2007, cf. Scott, 2012) ${ }^{1}$. According to McCann and Acs (2011: 29), city regions need a minimum population threshold of approximately 1.5 to 2 million people to achieve a competitive rate of knowledge-related agglomeration effects. In the context of the Netherlands or Belgium, with their dense patterns of historically relatively independent small- and medium-sized settlements, metropolization entails a tendency towards greater functional interdependencies between these settlements inducing larger polycentric functional urban regions (Champion, 2001; Meijers et al., 2014). Nevertheless we should be wary not to overstate the relevance of the present conjuncture on economic geographies. Any assessment of the economic performance of contemporary metropolitan regions needs to take path dependencies into consideration (Pain et al., 2015).

In this chapter, we examine metropolization as a new episode of the historical development of Belgium's urban system. Belgium is a small country of about 11,2 million inhabitants, located in Western Europe. The northern half of the country is strongly urbanized, taking on a suburban sprawl-like morphology interspersed with historical cities and villages (Antrop, 2004). The resulting fragmented landscape is locally known among planners and urbanists as the 'nebular city' ${ }^{2}$. This metaphor is apt: aerial

\footnotetext{
${ }^{1}$ Although part of a broader theoretical claim that remains unexamined in this chapter, Scott's (2012) claims about the emergence of a new 'cognitive-cultural economy' discusses the same agglomerative mechanisms as Krätke's (2007) 'metropolization'.

${ }^{2}$ The term 'nebular city' ('nevelstad' in Dutch) was adopted from the Italian concept of città
} 
photographs of the region show a sprawled urban topography reminiscent of a nebula, even when compared to the neighboring polycentric regions of the Dutch Randstad and the German Rhine-Ruhr area (cf. Albrechts, 1998). While such morphology might convey the impression of homogeneity, the regularity of the nebula on the map hides a long and turbulent history that strongly shapes Belgium's contemporary culture, politics and economy.

Although Belgium has long been a unitary state, during the last fifty years, it witnessed a gradual process of devolution that resulted in three largely autonomous regions: Dutchspeaking Flanders in the north, French-speaking Wallonia in the south and the multilingual Brussels Capital Region (BCR). With increasing regional autonomy, the economic narratives of the three regions have diverged. While Wallonia is represented as a region that is slowly recovering from harsh deindustrialization in the 1970s and 1980s (Van Criekingen et al., 2007), Flanders is described in the terms of a 'post-Fordist' narrative of urban networks (idem), and the BCR represents a truncated world city squeezed by institutional barriers (idem; Kesteloot and Saey, 2002). However, to what extent does metropolization integrate older socio-spatial structures? How does the (alleged) emergence of a metropolitan region in Belgium relate to often-invoked spatial imageries such as the Flemish Diamond, the Walloon Triangle, Greater Brussels, or a larger area that might be more reminiscent of the ABC (Antwerp-Brussels-Charleroi)Axis of yesteryears' Belgian unitary state?

In order to answer these questions, this chapter presents an investigation of metropolization based on the spatial structure of Belgium's labor market using Vasanen's (2012, 2013) connectivity field method. After elaborating the theoretical concepts of agglomeration-economy regimes, metropolization, and regionalization, and discussing their spatial-economic implications in Section 6.2, we will provide a concise overview of the historical regionalizations of the Belgian urban systems in Section 6.3. Sections 6.4 and 6.5 will discuss the connectivity field method as applied to the Belgian case. Section 6.6 will conclude by reflecting on the tensions generated by the mismatch between economic geographies and geographical imaginations about Belgium.

\subsection{Agglomeration-economy regimes}

Since the advent of the industrial revolution, the role of technology in the evolution of the spatial economy has been cyclical and has largely followed the pattern of Kondratieff cycles (see Boschma, 1994 and Vandermotten et al., 2010 for respective evolutionaryinstitutionalist and political-economy elaborations of Kondratieff cycles in the Belgian context). Kondratieff cycles last between 45 and 60 years and consist of distinct 'A' and 'B' phases. The A phase is a period of strong economic growth where several basic and a

diffusa. Who exactly first introduced the term in Dutch is unclear, but it quickly became widespread in Flanders, undoubtedly due to its intuitive appeal in the Flemish context (Dehaene and Loopmans, 2003). 
cluster of related innovations emerge in a short period. These basic innovations usually concern general-purpose technologies (steam, railroads, cars) that fuel tremendous productivity growth, transform mobility systems, and lead to growth spirals based on local economic endowments (Boschma, 1994). The B phase of each cycle consistently implies diminished growth, gradual diffusion of innovations, and a relative scarcity of profitable investments. Historically, the key mobility technologies of the A phase have tended to give rise to time-space compression (Janelle, 1969), resulting in growth in the size of the Functional Urban Area (FUA). Consequently, each Kondratieff cycle resulted in distinctive urbanization geographies, that is, agglomeration-economy regimes. Sometimes labor was the dominant structuring mechanism in these regimes, sometimes capital, a complexity compounded by changing modes of transport. Economic historians have established three and a half Kondratieff cycles that are more or less undisputed. The last undisputed cycle was the end of the Fordist era in the 1970s that corresponds with the passage from the $\mathrm{A}$ to the $\mathrm{B}$ phase of the fourth cycle. Analyzing (drivers of) the subsequent period has been a source of academic contention ever since. Empirically, it is observed that in an initial post-Fordist phase in the 1980s, agglomeration economies increased in importance again in the Global North, but only to a limited degree in historic inner cities (Scott, 1988a; 1988b). Since the 2000s, the urban resurgence has intensified (Turok and Mykhnenko, 2007; Scott, 2012) involving the whole city-region, with intensifying centripetal forces and large metropolitan centers as renewed focal points (Scott, 2012), although there is considerable spatial variation in this regard (David et al., 2013; Dijkstra et al., 2013). It is this post-2000 agglomeration-economy regime that we denote with metropolization (Krätke, 2007).

Settlement geographies are a path-dependent result of the agglomeration-economy regimes that were present when urbanization occurred. Agglomeration-economy regimes induce migration, urbanization, and infrastructural development that further structure the evolution of the urban system (van der Knaap, 1980). As people settle, acquire real estate, and routinize their day and life paths they become dependent on these sociospatial urban scales (Cox and Mair, 1988; [Chapter 4]). Moreover, specific routinized interactions over the longue durée generate the discursive material for the economic imaginaries, mental maps, and regionalizations that subsequently inform senses of belonging and political narratives (Allen et al., 1998; Oosterlynck, 2010), even if these mental maps diverge from material reality. In the long term, the socio-spatial artifacts of different agglomeration-economy regimes get absorbed in new scales, but are also superimposed on top of each other in a palimpsest kind of manner (Harvey, 1996: 49). This generates a layered structure of social relations consisting of the social and demographic inheritance, spatial and social imaginaries, and built environments of different eras of spatial divisions of labor (Massey, 1979; Harvey, 1996; Allen et al., 1998; Albrechts, 1998).

Already in the 1930's, McKenzie (1968 [1933] [cf. Chapter 5]) observed that urban-rural relations between the traditional city and its hinterland had dissolved in 'metropolitan communities'. Drivers of this process were identified as a deepening division of labor in conjunction with adoption of mobility technologies. Scott (1988a: 121) defines a 'modern 
metropolis as a bipartite system of production and social spaces tied geographically to one another by commuting habits [...] of workers'. For much of the twentieth century, metropolitan development implied a centrifugal fanning out of the functional urban area. However, it is plausible that as the economy has become more knowledge-insensitive and based on flexible labor relations, a renewed centripetal layer of social relations is deposited on the existing urban fabric, i.e. metropolization (Krätke, 2007; Scott, 2012).

In metropolization, deep and thick labor markets are paramount (Scott 1988a; 2012). Interpreting McCann and Acs (2011), it is the division of labor enabled by a concentration of 1.5 to 2 million people that allows the degree of diversification and specialization that enables an urban region to integrate in the global urban networks that are associated with contemporary economic growth (Scott, 2012; Taylor and Derudder, 2016). However, this general statement requires qualification. First, a metropolitan region can comprise a polycentric system of smaller settlements (David et al., 2013; Dijkstra et al., 2013). Second, Krätke (2014) urges to cautiously observe differences between 'real economy' and 'financial economy' trajectories of metropolitan regions - where the latter trajectory is related to financial accumulation and real estate speculation (cf. Bassens and van Meeteren, 2015). Lastly, David et al. (2013) and Pain et al. (2015) advocate critical scrutiny of network perspectives that do not take the wider economic-geographical structure and history into account (cf. Chapter 3). These cautions inform our elaborate scale-sensitive historical methodology.

\subsection{A Concise History of the Belgian Urban System}

The Belgian economic-geographic historiography commonly utilizes a Kondratieff cycle periodization to chart the country's spatial-economic transitions over time (Vandermotten, 1998). Phelps and Ozawa (2003) augment this perspective through providing an explicit historic-geographical theorization of agglomeration economies. They propose four ideal-typical forms dominant in different historical eras of capitalist development: proto-industrial, industrial, late-industrial, and post-industrial ${ }^{3}$ agglomeration economies. Although Phelps and Ozawa (2003: 585) mention the importance of technological change to understand the changing geography of agglomeration economies, they do not elaborate that point further. Yet the typology follows largely similar temporal boundaries as standard Kondratieff cycle theory since it describes the same historical changes. By juxtaposing Vandermotten's Kondratieff periodization with Phelps and Ozawa's typology we obtain a fivefold agglomerationeconomy regime typology fitting the development of Belgium's urban system: protoindustrial (until 1840), industrial-A (second Kondratieff cycle 1840-1895), industrial-B (third Kondratieff cycle 1895-1948), late-industrial (the A phase of the fourth Kondratieff cycle 1948-1974), and post-industrial (from 1974 onwards). Figures 6.1 and 6.2 provide reference maps of contemporary population density and the Belgian administrative and

\footnotetext{
${ }^{3}$ The utilization of the term 'post-industrial' is to provide consistency with the literature. This should not be understood as an a priori endorsement of post-industrial theory.
} 
city systems.

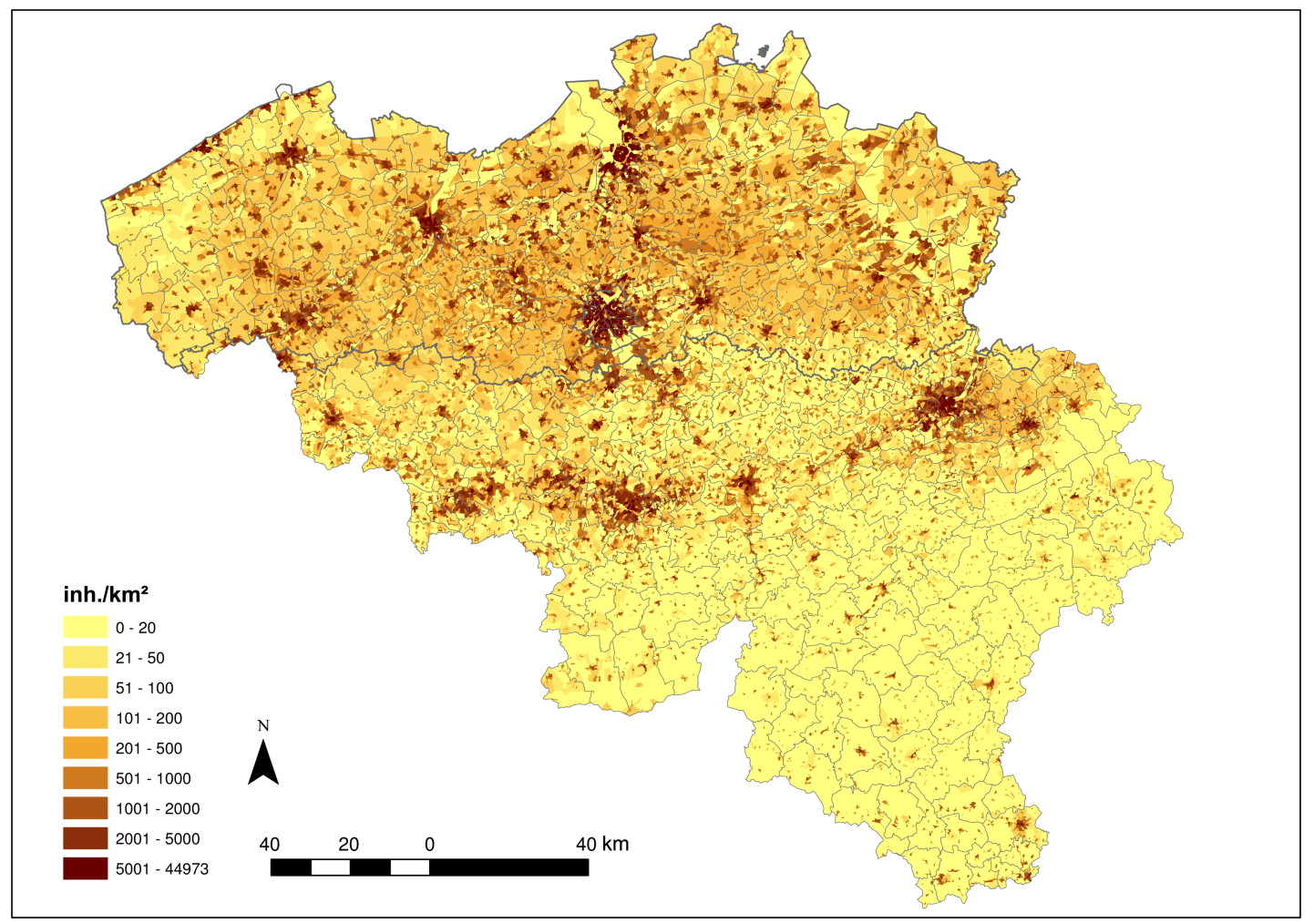

Figure 6.1 Population density in Belgium (Source: Statistics Belgium, 2010) 


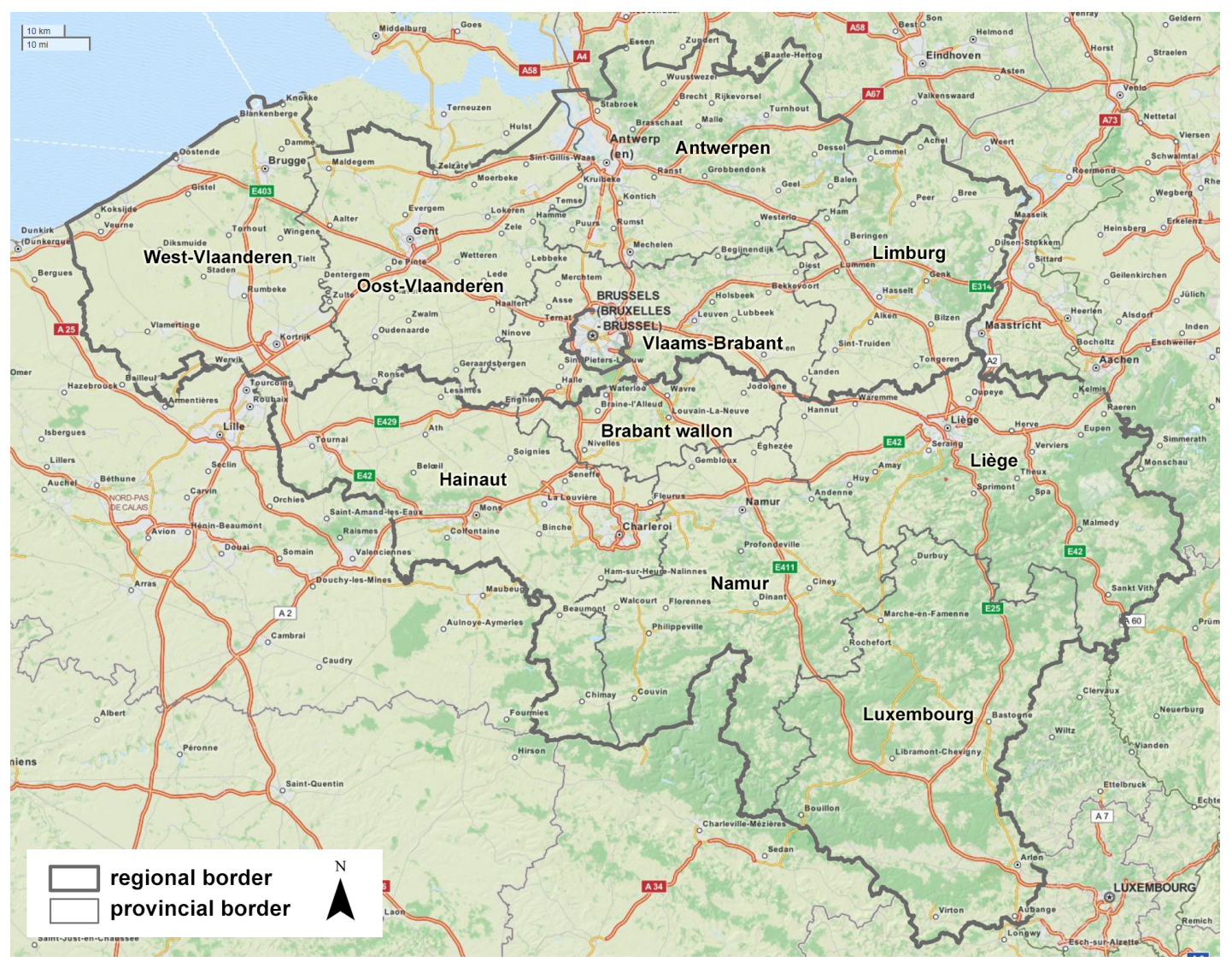

Figure 6.2. The Belgian administrative and city systems (Source: Open Street Map, Creative Commons Licence, 2014)

\section{Central Places: The Belgian Proto-Industrial Urban System}

Although the present-day Belgian settlement system has some roots in the Roman era (Arlon, Tournai, Tongeren) (Vanneste, 1985), the northern anchors of its current structure largely emerged during the Medieval period (Braudel, 1984: 98). The kernels of the city system formed around strategic points on fluvial transportation routes on the banks of the Scheldt-Leie (e.g. Antwerpen or Antwerp in English, Gent or Ghent, Tournai) and Meuse (e.g. Liège, Huy, Namur, Dinant) rivers, while the in-between space remained relatively unpopulated (Vandermotten and Vandewattyne, 1985; Vanneste, 1985). In the thirteenth century, the economic pivot shifts towards the North Sea as the city of Brugge (Bruges), becomes one of the most important trading centers in the worldsystem of that era, while nearby Ghent becomes the center of the world textile industry (Braudel, 1984; Abu-Lughod, 1989). The surroundings of these cities-roughly equivalent with present-day West-Vlaanderen, Oost-Vlaanderen, Vlaams-Brabant, Brabant wallon and the western part of Antwerpen provinces-develop a densely populated market based settlement system congruent with central place logic (Vandermotten and Vandewattyne, 1985; Van Nuffel and Saey, 2005). In the fourteenth century, the Ghent textile industry diffuses in the neighboring countryside (Abu-Lughod, 1989: 85), giving an impulse to a 
long-lasting rural proto-industrial putting out system of small family-based cottage industries (Musyck, 1995; Vandermotten 1998). While the position of Bruges is eventually overtaken by Antwerp in the fifteenth century, before moving on to Amsterdam after 1585 (Braudel, 1984), Brussels gradually becomes an important administrative center under the various political regimes that rule present-day Belgium. During the period of the United Kingdom of the Netherlands (1815-1830), Brussels also becomes a financial center (Vandermotten et al., 1990). This marketplace-based city system with its center of gravity in the north of the country would gradually draw the surrounding countryside within its economic orbit (De Wachter and Saey, 2005) congruent with the trade-based agglomeration-economy regime dominant in the protoindustrial era (Phelps and Ozawa, 2003; Scott, 2012). Shortly after independence from the Dutch in 1830, Belgium has five cities with over 30,000 inhabitants (Brussels, Antwerp, Ghent, Bruges, and Liège), all of them located in the northern and central parts of the country alongside a few smaller historical settlements based on the river system in the center-south (Van der Haegen et al., 1982: 275; see Figure 6.4a in Section 6.5).

\section{The Walloon Axis: Belgian Urban System Development in the Second Kondratieff Wave (1840-1895)}

Soon after independence, Belgium becomes the first continental European country to industrialize. Given the paramount importance of transport costs in this era, industrialization and related urbanization take place there where natural resources are found (Hohenberg and Lees, 1995 [1985]; Vandermotten, 1998; Phelps and Ozawa, 2003: 591). Consequently, the coal-deposit areas of the previously thinly populated south in the Meuse-Sambre river basins develop vigorously. Besides the strong growth of existing cities such as Mons, Namur and Liège, previously marginal places such as La Louvière and Charleroi gain prominence (Vandermotten and Vandewattyne, 1985). However, Belgian industrialization develops unevenly within its arc-shaped Walloon MeuseSambre industrial axis (see Figure 6.4b in Section 6.5). High value-added industries only develop in those urban centers with historically built up knowledge bases. For instance steel industry develops in Liège, a historic center of artisanal metalworking but not in the Borinage region in Hainaut (Vandermotten, 1998; cf. Boschma, 1994). Furthermore, due to its underdeveloped demographic weight, the Walloon industrial axis had severe labor shortages, preventing the eastern and western part of the axis from coalescing and developing complementarity (Vandermotten et al., 1990: 17; Vandermotten, 1998). According to Vandermotten (1986: 55), the Walloon Axis is spatial metaphor that suggests a functional coherence that never existed in reality. Meanwhile, in the more strongly urbanized north, only the Ghent textile industry is is able to adapt to the new technological imperatives of industrialization. The rural, proto-industrial, textilemanufacturing sector based on the putting-out system quickly collapses under the weight of international competition, pauperizing the population (Vandermotten et al., 1990: 16). Although some migrate toward the south, the Belgian ruling elites decide on a different scheme to counter the spatial mismatch between labor supply and demand. The Belgian steel and railway industries roll out the largest railway network in the world, with support from the government who sponsors railway subscriptions for laborers (De Block and 
Polasky, 2011). By the 1890s, more than two million (!) people commute to work every day (De Decker, 2011: 1640). Commutes totaling four hours a day are not uncommon and will ultimately stimulate a commuting culture that is still very present today (idem). The added advantages for industry are that the rural laborer can be 'protected' from unionization and secularization, while wages can be kept low as the laborers' family is de facto semi-proletarianized through the continued prevalence of subsistence farming (Mandel, 1963). In this era, the hilly south of Belgium (the Ardennes) and the forested and infertile sandy area in the north, which starts east of Antwerp (the Kempen, Campine in English), retain a traditional peasant character (Vandermotten et al., 1990: 21-22).

\section{The ABC-Axis: Belgian Urban System Development in the Third Kondratieff Wave (1895-1948)}

The economic-geographic history of Belgium cannot be properly understood without appreciating the role of centralized holding banks, of which the Société Générale de Belgique (incorporated in 1822, acquired in 1998 by the French company Compagnie Financière de Suez) is the major example. When capital centralizes in a context of capital scarcity, as was the case during large parts of the nineteenth and twentieth centuries, a decision to invest in one location implies a lack of investments elsewhere (Mandel, 1963; Vandermotten, 1998). It was the Brussels-based large holding banks that chose to invest in the Walloon Axis in the nineteenth century, shifting their spatial strategy toward the north and to foreign countries in the early twentieth century (Vandermotten, 1998). For Belgium, 1890-1950 is a period diminished growth where domestic industrialization strategies are partly substituted for foreign adventures by the holding banks (Mommen, 1994: 34; Vandermotten, 1998: 84). Domestic Investments are diversified toward electric appliances, non-ferrous metals and petrochemicals. Raw materials are imported from overseas, largely from Belgian Congo, and semi-finished products are re-exported. Spatially, a new development axis, perpendicular to the old Walloon Axis, develops between the cities Antwerp, Brussels and Charleroi (the ABC-Axis; Vandermotten et al., 1990). Brussels and Antwerp, proximate to consumers and the labor force, become important industrial centers. (Vandermotten, 1998: 85). Meanwhile, the Walloon Axis remains specialized in the nineteenth-century heavy industries. Hampered by the holdings' lack of willingness to invest capital (idem) and its weak demographic basis, the region starts to stagnate (Vandermotten et al., 1990). This shift northward is exemplified by the fact that by 1920 half of the activities of Société Générale in Belgium are located in Flanders (De Wachter and Saey, 2005: 161).

Furthermore, in the late nineteenth century, The Campine region, located strategically between the Antwerp harbor and the German hinterland, is opened up through canals (Vandermotten et al., 1990). Dirty industries spill over from Liège and Antwerp, and coal pits are established in Limburg following the First World War. While the coal industry induces strong demographic development, the region remains peripheral until the 1950s (Kipnis and Swyngedouw, 1988: 151; Boschma, 1994: 118). The geographic centralization of capital in the $\mathrm{ABC}$-Axis is further strengthened by the arrival of new industrial players. By the 1920s, enterprises in Flanders are developed with autonomous Flemish capital, 
organized around Dutch-speaking catholic elites (Oosterlynck, 2010). The 1920s also witness the arrival of foreign direct investment (FDI) from the United States (USA): both Ford and General Motors start operating in the Antwerp harbor (Vandermotten, 1998: 86-87), as stimulated by tariff policies from 1935 onwards (Boschma, 1994: 115; Mommen 1994: 94). Meanwhile, the state continues to reinforce a non-urban culture. While in 1889, a law is enacted that prohibits the construction of large-scale workingclass quarters and encourages rural homeownership for laborers (De Meulder et al., 1999; De Decker, 2011), in 1928 subsidized loans for homeownership for large families are introduced (De Decker, 2011: 1641). By around 1945, this fostered the development of the geography depicted in Figure 6.4c in Section 6.5.

\section{Belgian Fordism in the Late-Industrial Era (1948-1974)}

Belgian economic development in the 1950s and 1960s is a textbook example of a Fordist accumulation system (Swyngedouw, 1990). The Fordist period is so memorable that the decades are still referred to locally as the 'Silver Fifties" and the "Golden Sixties". In the 1950s, corporations from the USA massively internationalize toward Europe due to growth exhaustion in the US domestic market (idem). Meanwhile, the Belgian government becomes conscious of its dependence on basic industries slated for restructuring within the newly minted European Coal and Steel Community (ECSC) [1952], and starts to make plans to diversify the economy (Ryckewaert, 2011). These include the expansion laws $[1959,1966]$, which create an attractive tax climate to lure foreign corporations, chiefly US FDI (idem; Vandermotten, 1986; Mommen 1994: 122). The state also executes an ambitious highway and canal plan to provide ample space and infrastructure for large-scale economic development (Ryckewaert, 2011). Completely in line with the Fordist paradigm, where the government supplies and subsidizes the preconditions for private capital accumulation, the 'De Taeye law' [1948] is enacted that fiscally promotes homeownership for Belgian families and helps set off a consumption spiral of suburban living and car ownership (De Meulder et al., 1999). By the 1960s, all the elements are in place for the late-industrial agglomeration-economy regime in the dispersed form of an urban field (Friedmann and Miller, 1965).

The regional effects of these measures confirm Friedmann and Miller's (1965) predictions: the outer boundaries of the urban system expand and economic growth diffuses. The strategically located Campine area develops an intensive branch plant economy. Conducive to this development are a coal industry induced labor surplus, lower wages than in the rest of the country, and sudden accessibility through new infrastructure-in particular the bundle of the Albert Canal [1939] and the Koning Boudewijn (A13/E313) motorway [1958] (Kipnis and Swyngedouw, 1988; Swyngedouw, 1990). Furthermore, the harbor complexes in both Antwerp and Ghent and the north of the ABC-Axis continue to strongly develop (Vandermotten, 1998). However, these expansions are oriented toward suburban or peri-urban development rather than to the core city (idem; Ryckewaert, 2011). The key exception is Brussels, which from the 1960s onwards starts to rapidly deindustrialize, and loses population due to suburbanization (Kesteloot and Saey, 2002). Simultaneously, Brussels is actively promoted as a tertiary 
growth pole (Ryckewaert, 2011) and becomes the headquarters of several European Institutions. While these developments induce strong central business district (CBD) formation, most CBD employees nevertheless commute inwards (Boussauw et al., 2012), contributing to population peaking in 1967 (Kesteloot and Saey, 2002). These are all signs that two other features of the late-industrial agglomeration-economy apply: decentralization of production and centralization of control (Scott, 1982, Phelps and Ozawa, 2003). Another area that develops strongly in the Golden Sixties is the southwestern part of Flanders, around Kortrijk, where the traditional flax industry is successfully diversified toward exports of, for example, carpets and wooden chipboards. This economic renaissance occurs relatively independently of the economic core area as Labor, capital, entrepreneurship, and technology are local affairs, making the region an example of a successful new industrial district in the 1990s (Musyck, 1995).

For Wallonia, by contrast, the Golden Sixties are rather greyish. The region is hit hard by the closure of the coal pits and the ageing basic industries (Vandermotten, 1986). The ECSC stipulates that the least productive (and hence the old Walloon) European mines are to be closed first and economic aid is made contingent on painful industrial restructuring (Ryckewaert, 2011). Similar to Flanders, industrial policy focuses on linear development, here pivoted around the new Autoroute de Wallonie [A15/E42], connecting the Ruhr area to Paris, which is expected to revitalize the Walloon Axis by fostering the development of new industrial estates (Vandermotten et al., 1990: 42 ; Ryckewaert, 2011). Although some new investments are secured, they are less prominent than in Flanders and do not offset the losses in the old industries (Vandermotten, 1986; Mommen, 1994: 127). Consequently, the demographic and economic weight decisively shifts back to Flanders (Vandermotten, 1986, 1998). It is in this context of uneven regional economic and demographic development that the lingering political conflict between the Dutch and the French speaking populations of Belgium explodes in the late 1960s (Witte et al., 2005). Although there had been calls for the federalization of the country from the Flemish side for decades, and the language struggle was an important rallying point for these demands, it is not before Walloon socialist elites decided that autonomy might help them tackle the economic woes that constitutional reform and federalization become politically feasible (Vandermotten et al., 1990: 60-62; Mommen, 1994: 128; Witte et al., 2005: 419-440; Oosterlynck, 2010: 1169).

\section{Competing 'Post-Industrial' Imaginaries: 1974- the Present?}

As an industrial country heavily reliant on the propulsive and capital goods sectors, Belgium is severely struck by the crisis of the 1970s, signaling the demise of the Fordist era and late-industrial agglomeration-economy regime (Mommen, 1994: 146-174). Once again, the losses are unevenly distributed geographically and the old industry in Wallonia and Brussels suffers more than the newer industry in Flanders (Vandermotten, 1986). In the midst of painful economic restructuring and in part due to the regional political tensions caused by crisis management (Witte et al., 2005), the Belgian state is federalized through a series of constitutional reforms. These reforms result in the devolution of policy fields such as spatial planning, industrial policy [1980], and public works [1988] 
(Oosterlynck, 2009; Boussauw and Boelens, 2015). Consequently, the newly minted regional governments, (1980/1981 for Flanders and Wallonia and in 1988/1989 for Brussels) start constructing new spatial-economic discourses and imaginaries, drawing on locally dominant perceptions and assessments (Oosterlynck, 2009, 2010).

Although there is broad consensus that Fordism ended with the crises of the 1970s, academic debates on after-Fordism and its spatial expression have never been fully resolved (Keil and Ronneberger, 1994). Tellingly, in 1984, Peter Hall speculates in the postscript to the third edition of his book 'The World Cities' that his earlier assertion of an 'urban future' might need nuance and that this future could also entail further dispersion and urban-to-rural migration instead (Hall, 1984: 230-253). This ambivalence is echoed in Phelps and Ozawa's (2003: 595) Peter Hall-inspired discussion of postindustrial agglomeration economies. 1980s' economic-geographical theorizing suggests bundled dispersal of economy activity away from the traditional urban centers (Scott, 1988b: 178), a development confirmed in contemporary analyses of the Belgian spatial economy (Cabus and Vanhaverbeke, 2003). Combined with the political and cultural discourse of federalization, this centrifugal urbanization popularized 'new regionalist' discourses that de-emphasize the role of the unitary state and traditional large cities among the newly minted Belgian regions (Oosterlynck, 2009, 2010).

Flemish new regionalism of the 1980s and 1990s emphasizes regional economic autonomy (Oosterlynck, 2009) and idealizes Southwest Flanders as the Flemish industrial district (Musyck, 1995; Reid and Musyck, 2000). Additionally, as studies reveal the significant innovative capabilities of the branch plants in the Campine region, Limburg seems to be ready for new regionalism too (Kipnis and Swyngedouw, 1988; although Swyngedouw, eg. 1990, would later qualify these claims). The appeal of urban dispersal even reaches the point where retention of economic activity in the central Flemish urban area-due to competition in the Campine and Southwest Flanders-becomes a policy issue (Vanhaverbeke, 1998; Albrechts and Lievois, 2004: 357). In the 1997 spatial structure plan for Flanders (RSV, 1997), this central area is baptized "The Flemish Diamond'. Four cities (i.e. Antwerp, Ghent, Leuven and-interestingly, since it is outside Flemish jurisdiction-Brussels) are to be considered a polycentric urban network that is able to compete with similar networks like the Dutch Randstad and the German Ruhr Area (Albrechts, 1998). According to Albrechts (1998: 420-421, corroborated by Vanhaverbeke, 1998; but questioned by Vandermotten et al., 2006 and Van Crieckingen et al., 2007) there was 'ample evidence' that the Flemish Diamond had the characteristics of a functional region, although it was regarded an 'urban network in the making' since organizational linkages and a shared regional imaginary were are absent when the spatial structure plan for Flanders was conceived. Hence, the Flemish Diamond is an aspirational policy notion that reflects emergent social-spatial realities (Albrechts and Lievois, 2004). Eventually, the Flemish Diamond becomes an important example of a polycentric urban region in the international literature (van Meeteren et al., 2015).

Walloon new regionalism similarly turns to the image of a polycentric region. Regarding reluctance by Flanders- and Brussels-based elites to invest in Wallonia as an important cause of the Walloon slump, the region initially aims for an independent revitalization of 
the Walloon industrial axis (Vandermotten et al., 1990; Oosterlynck, 2009). In 1986, the regional capital is established in Namur, which is only the third city in Wallonia, and the administrative functions are spread over various cities as a 'polyville Walonne', a strategy strongly criticized for its naivety (Vandermotten 1986; Vandermotten et al., 2006). When the economy gradually starts to recover in the late 1980s and 1990s, it is particularly the Brabant wallon province that exhibits growth, while the outer edges of the Walloon industrial axis compete with one another (Vandermotten et al., 1990). This unevenness is attributed to the presence of technological research and development activities and spillovers from Brussels in Brabant wallon (Reid and Musyck, 2000). These developments are incorporated into the Walloon spatial plan (SDER, 1998) that reveals the spatial concept of a Walloon Triangle connecting the axis Mons-Charleroi-Namur and Brussels. Like the Flemish Diamond, the Walloon Triangle is only considered to have limited validity as an empirical spatial object, but is meant to emphasize the interdependency between Brussels and Wallonia (Van Criekingen et al., 2007; see Figure 6.4d in Section $6.5)$.

This strong emphasis on new regionalism, together with the administratively constrained size of the BCR, has long obscured Brussels' economic renaissance, which becomes increasingly apparent from the 1990s onwards (Kesteloot and Saey, 2002). After 25 years of absolute population decline, the BCR's net population starts growing again after 1996 (idem). Furthermore, the tertiary complex, based on the international institutions complemented by business and tourist travel, augments its contribution to the GDP (Vandermotten et al., 2009). Moreover, when considering the functional urban area rather than the restricted administrative boundaries of the BCR, a case can be made for a growth center mechanism based on the core city spreading out toward Flanders and Wallonia (Vandermotten et al., 2006; Thisse and Thomas, 2010; cf. Chapter 4). This casts doubt on the dispersal narrative that has been the hallmark of the Belgian variety of new regionalism (cf. Riguelle et al., 2007). However, despite these indications of the renewed relevance of Brussels to the Belgian national economy, the most recent round of regional policies in Flanders and Wallonia reinforce the old centrifugal narrative by stressing regional ruptures between the Flemish and Walloon regions (van Oudheusden et al., 2015). These ambiguities and tensions between spatial imaginary and economic geography set the stage for the following analysis of contemporary metropolization in Belgium. 


\subsection{Labor Market Connectivity Analysis: Data and Method}

From a metropolitan perspective, commuting data provides an important indicator of economic interdependency between geographical entities (Scott, 1988a). The more a labor market integrates multiple settlements, and the higher its total mass, the more likely it is that the required skill-specialization threshold for metropolization is met. Recently, Vasanen $(2012,2013)$ developed the 'connectivity field method' (CFM) that allows interrogation of these interdependencies. The CFM is a variation of more traditional methods of spatial interdependency analysis, and relies on the interaction between spatially defined entities such as municipalities, census blocks or traffic analysis zones, with the aim of providing an analysis independent of predefined boundaries. This independence regards all spatial demarcations except the data container, which in our case refers to municipalities. Just as in the classic gravity model (Stewart, 1948), Vasanen's method is capable of measuring interaction by means of flows of traffic, telephone communication, or data transfer. In the present study, following one of Vasanen's case studies $(2012,2013)$, we use commuting flows. Although covering a rather small share of daily mobility patterns, these flows highlight the regional labor market interdependencies that are theorized to be crucial in metropolization. Another important reason for using commuting flows is the availability of high quality data in Belgium.

The CFM employs an origin-destination matrix of regional interactions and proposes three analytical concepts: the 'connectivity field', the 'potential field', and the 'level of connectivity'. The connectivity field of a specific zone within the study area is defined as the spatial distribution of the origins of interactions (e.g. trips) arriving in the considered zone. Translated into commuting flows and municipalities, this points to the spatial distribution of the working population that is employed in the studied municipality. The second analytical concept, the potential field, is defined as the spatial distribution of the departures of all interactions in the entire region under study, with the exception of intrazonal trips. Translating this concept in terms of commuting flows and municipalities, this concept regards the spatial distribution of the residences of those who work in another municipality than where they live. Both distributions can be visualized on a map. While the connectivity is represented by as many maps as there are zones in the studied region, the potential field is represented by only one map for the entire region (Figure 6.3). The third and final concept, the 'level of connectivity', is defined as the Pearson's correlation between the connectivity field and the potential field, and is calculated separately for each zone. This connectivity metric indicates the extent to which the spatial distribution of the incoming commuter flows of the considered zone is similar to the spatial distribution of the outgoing commute in the entire region. A positive value indicates that the local labor market is embedded in the region, while a value near or below zero indicates that the local labor market operates autonomously, and perhaps even depends on zones outside the studied region. Since the dataset regards a population and not a sample, we do not consider statistical significance thresholds. 

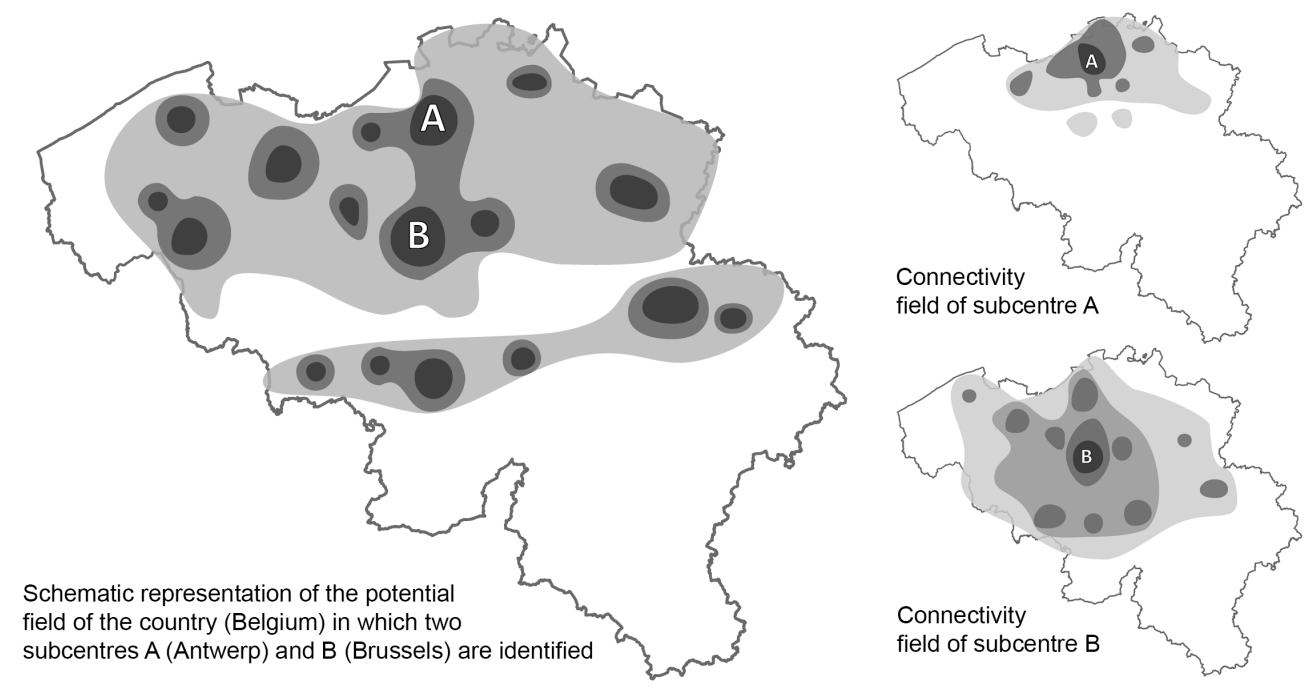

Figure 6.3. Schematic representation of potential field and connectivity field (Based on: Vasanen 2012, 2013)

Methodologically, a few caveats apply. By ignoring the intra-municipal commute, the importance of central cities with a positive jobs-housing balance is somewhat underestimated. As a corollary, the calculated connectivity indicates how well the area in question is linked to the labor market of the entire region studied, but ignores the economic activity represented by the internal commute of the zone. The advantage of the CFM in this respect is that the analysis act as a kind of filter that allows us to squint away the dominance of historically grown concentration patterns and reveals emergent indications of metropolization. Moreover, an unbiased connectivity assessment would require a system of spatial aggregation in which every zone would contain exactly the same number of jobs, meaning that zones would become smaller where employment density is higher. In that case, it would be reasonable to also include intra-zonal trips since variation in the number of such trips would no longer correspond with the (invariable) number of jobs per zone. In practice, however, this way of working is not feasible, since available data is usually aggregated into administratively defined fixed boundaries.

\section{Application to home-work travel in Belgium}

In Belgium, there is a long tradition of using commuting flows in mapping socioeconomic and spatial processes (e.g. Dickinson, 1957). Following the censuses of 1970, 1981, 1991 and 2001, which are generally perceived as being very complete, commuting data have been used to define urbanization classes, attributing an important role to the commute in the perception of urbanization processes, both in academia and among policy makers. The commuting data set utilized in this study dates back to 2010 (RSZ, 2011). We use this dataset to calculate the level of connectivity and spatial integration of the Belgian labor market. In addition, we mapped the connectivity field for the five largest 
cities (Brussels, Antwerp, Ghent, Charleroi and Liège). In the case of Brussels, for mapping purposes, we first aggregated the nineteen municipalities that make up the BCR. Such a move is vindicated since the Brussels municipality sensu strictu, contrary to the other cities, was never consolidated in the administrative reform of 1975 (Kesteloot and Saey, 2002: 56; cf. Corijn and Vloeberghs, 2009), which was enacted in 1977 and in Antwerp in 1983, respectively. After presenting the results of this analysis, we discuss the observed regional distribution of connectivity levels and the differences in the size of the connectivity fields of the five studied urban areas in relation to the spatial-economic structure of Belgium as it is portrayed in the relevant literature.

\section{Properties of the Social Security Data}

Our dataset is based on the central database of the Belgian National Social Security Office (NSSO). It takes the form of an origin-destination matrix with all 589 Belgian municipalities as aggregation zones. This database (details in RSZ, 2011) contains the residence and place of employment on 31 December 2010 of the large majority of Belgian employees. The registered residence is the address where the employee officially lives. The place of employment is the applicable branch address of the employer, which in some cases can differ from the place where the actual work is done. The database is generally known as very dependable, although the addresses are the least accurate part since data gathering relies on employers' self-reporting. As far as possible, missing data are supplemented by the administration of the NSSO.

While seen as reliable, there are several biases in the database. A limited number of people who are part of the current active labor force register in separate social security provisions, and are thus not included in the NSSO database. Staff members of municipal and provincial governments, seamen, and the self-employed in the strict sense (those who are not registered as an employee of their own company) are key examples. At the same time, employees with two or more places of employment, for example because they combine several part-time jobs in different organizations, appear several times in the database, again causing some bias.

\subsection{Findings}

Before examining the degree of integration of the Belgian labor market, it is important to properly gauge the relevant building blocks, both historically and contemporarily. Section 6.2 discussed the development of the Belgian urban system in regard to agglomerationeconomy regimes, concluding that by the end of the 1990s, a 'post industrial' geography of the Belgian urban system seemed to have solidified in harmony with the literature of the time, although the renaissance of Brussels posed questions to the endurance of this after-Fordist geography. Table 6.1 and Figure 6.4 summarize Section 6.2. In Figure 6.4 several maps of historical Belgian urban system regionalizations have been redrawn: 


\begin{tabular}{|c|c|c|c|}
\hline Regime & Period & $\begin{array}{l}\text { Dominant } \\
\text { Agglomeration logic }\end{array}$ & $\begin{array}{l}\text { Dominant Spatial Expression / spatial } \\
\text { narrative in Belgium }\end{array}$ \\
\hline Proto-industrial & $\begin{array}{l}\text { Before } \\
1840\end{array}$ & $\begin{array}{l}\text { Urbanisation around } \\
\text { market centres }\end{array}$ & $\begin{array}{l}\text { Central place system in Northern } \\
\text { Belgium }\end{array}$ \\
\hline Industrial A & $1840-1895$ & $\begin{array}{l}\text { Urbanisation based on } \\
\text { natural resources }\end{array}$ & Walloon industrial Axis \\
\hline Industrial B & $1895-1948$ & $\begin{array}{l}\text { Urbanisation based on } \\
\text { Population centres }\end{array}$ & ABC-Axis \\
\hline Late-Industrial & $1948-1974$ & $\begin{array}{l}\text { Dispersal of Production; } \\
\text { centralisation of control }\end{array}$ & $\begin{array}{l}\text { Dispersal of industry and population, } \\
\text { rise of Brussels as service growth pole }\end{array}$ \\
\hline Post-industrial & $\begin{array}{l}1974-(+/-) \\
2000\end{array}$ & $\begin{array}{l}\text { New regionalism based } \\
\text { on new industrial spaces }\end{array}$ & $\begin{array}{l}\text { Flemish Diamond, Walloon Triangle, } \\
\text { industrial districts }\end{array}$ \\
\hline Metropolization & $\begin{array}{l}(+/-) 2000- \\
\text { present }\end{array}$ & $\begin{array}{l}\text { Urban system } \\
\text { integration }\end{array}$ & Subject of the paper \\
\hline
\end{tabular}

Table 6.1 Agglomeration economy regimes in Belgium

We now extend these historical observations with the findings of our application of the connectivity field method to the current Belgian urban system. Figure 6.5 shows the connectivity fields-the distribution of places of residence for the employees registered to work in these cities-for the four largest Belgian cities other than Brussels (Antwerp, Charleroi, Ghent, and Liège). Note that Figures 6.5 and 6.6 show the intra-municipal travel-to-work activity as well. Figure 6.5 displays quite 'classic' monocentric functional urban areas in terms of labor markets. A degree of reciprocal interdependence is only present between Antwerp and Ghent. However, adding the BCR to the equation (Figure 6.6) changes the image dramatically. Not only is the size of the BCR labor market area significantly larger, it interacts to an important degree with the other four big cities. This relationship is not reciprocated by any of these four cities and therefore clearly hierarchical (Limtanakool et al. (2007: 2127).

Figure 6.7 visualizes the hierarchy and balance (Limtanakool et al., 2007; Burger and Meijers, 2012) of the intercity commuter flows. The nodes represent the urban agglomerations-aggregations of the core cities and their respective suburbs (Luyten and Van Hecke, 2007: 37)-allowing for meaningful comparison. Note that this implies that the Brussels urban agglomeration larger than the BCR and tri-regional since its agglomeration exceeds both the Walloon and the Flemish regional boundary (ibidem). The size of the nodes on the map represents the sum of the internal commute within the respective agglomerations and the incoming commute from the four other urban agglomerations. Arrows specify these incoming commuter flows. 

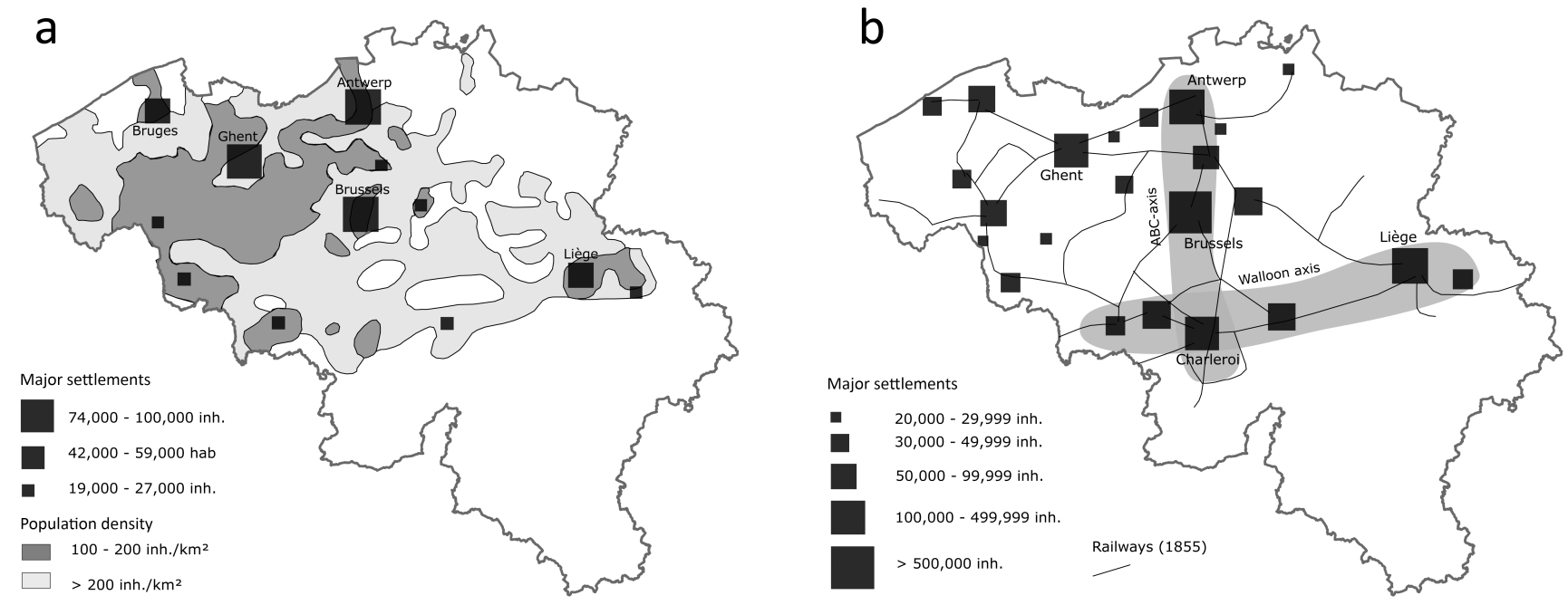

Figure 6.4 Development of the Belg urban system approximately 1830 ( 1910(b), 1945(c), 1998(d)

A) The Belgian urban system in 1830 , at dawn of the industrial era (Redrawn fr Vandermotten et al., 2010: 27).

B) The Belgian urban system in the indust era. (City population data (1910), Van Haegen et al., (1982), Paul Kevers' data railways were

http://www.dotinternet.be/visualisatie-

spoorlijnen-belgie-1830-1855/ Visited Febru 5, 2016.

C) The Belgian urban system at the dawn the late-industrial era (1945) (De Wachte Saey 2005: 162, slightly adapted)

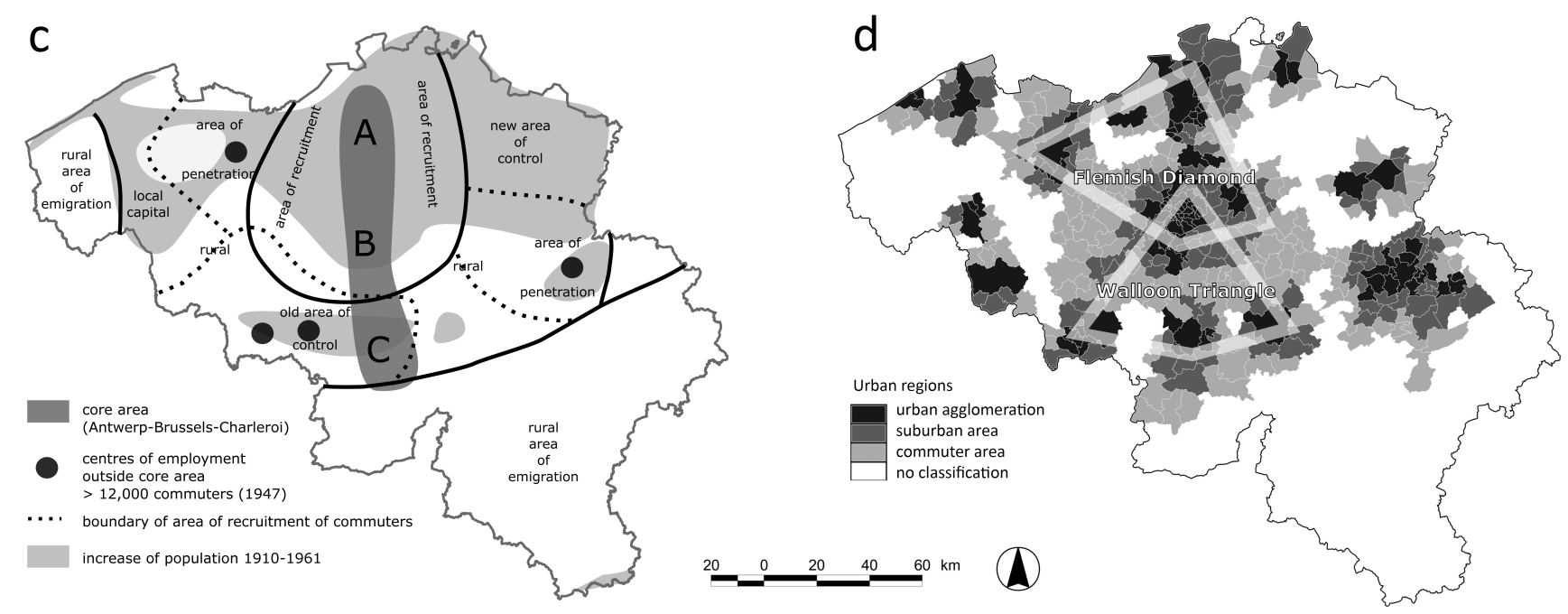

D) The competing imaginaries of the Belg urban system in the 'post-industrial' era (19 (Van Criekingen et al., 2007: 107). 


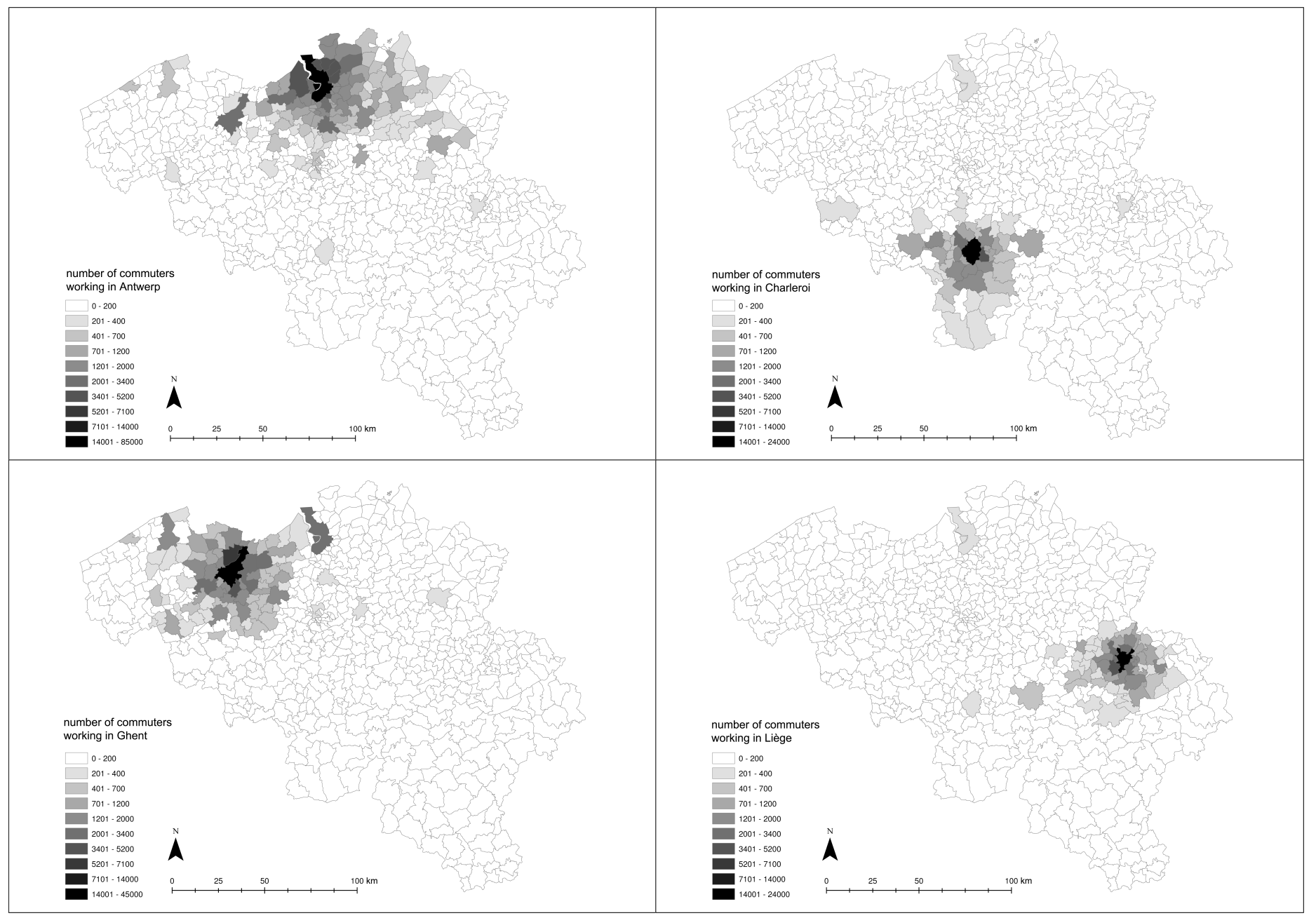

Figure 6.5 Connectivity fields of Antwerp, Charleroi, Ghent and Liège 


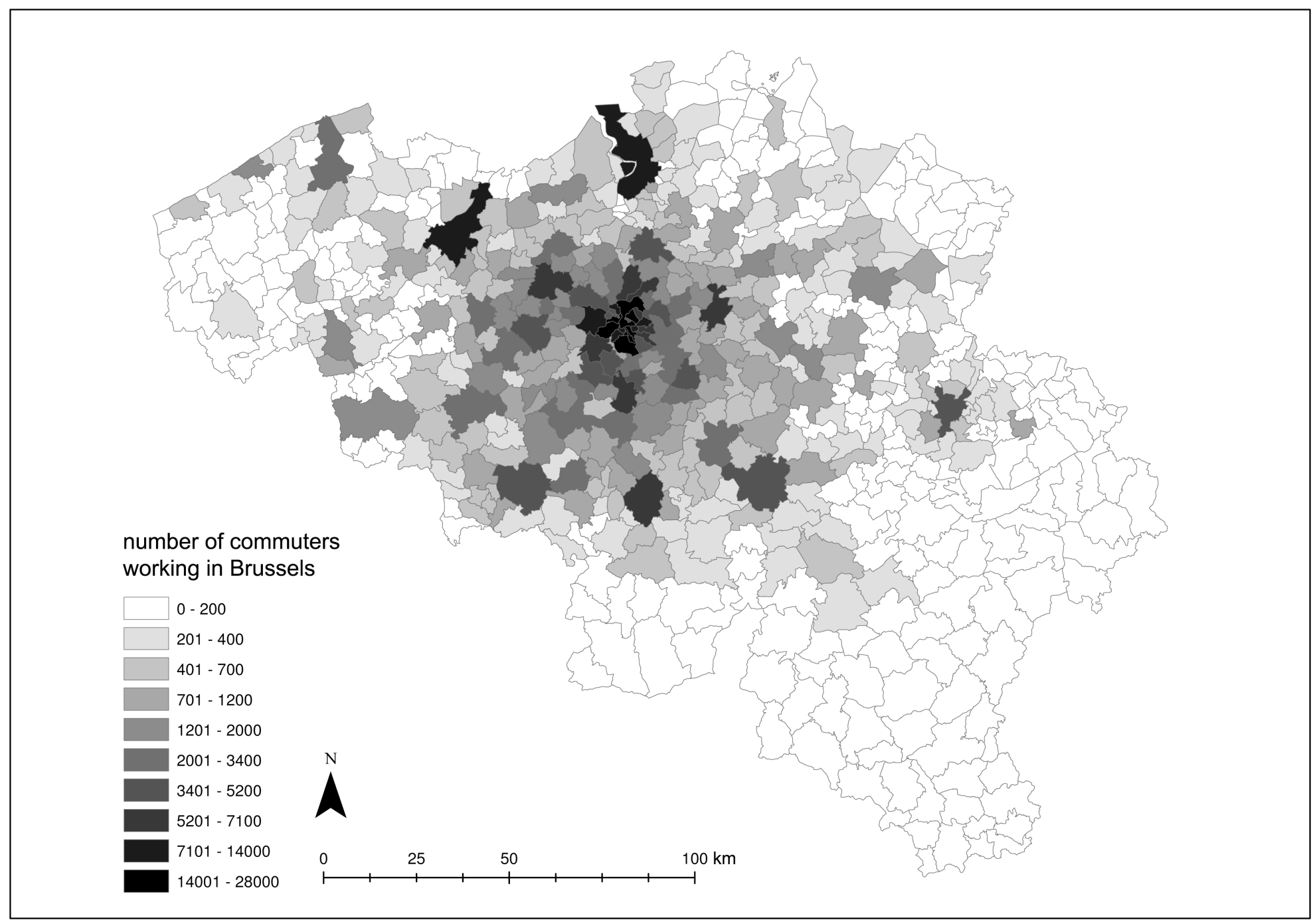

Figure 6.6 Connectivity field of the Brussels Capital Region 


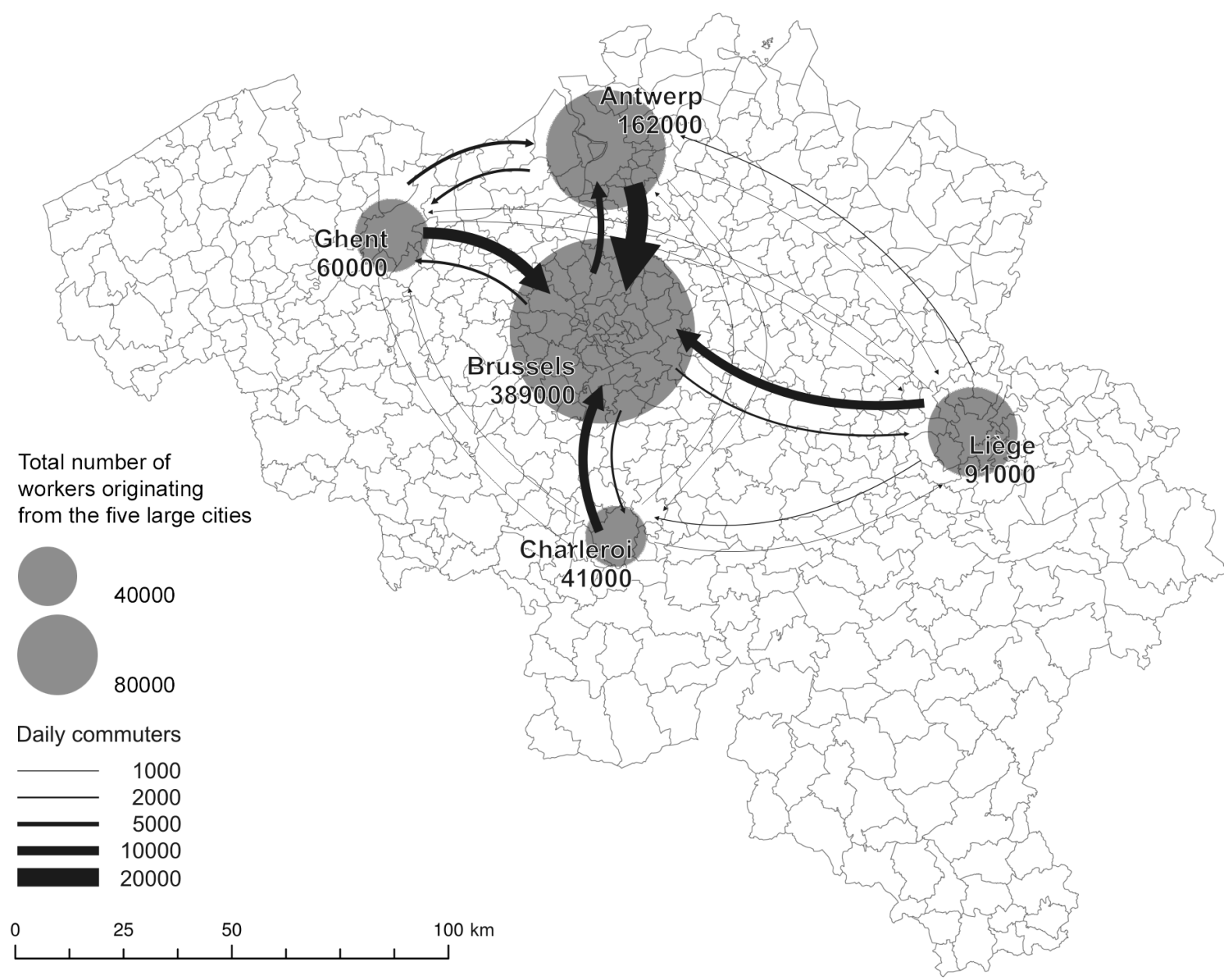

Figure 6.7. Commuting flows between the five largest Belgian urban agglomerations (Source: RSZ, 2010) 


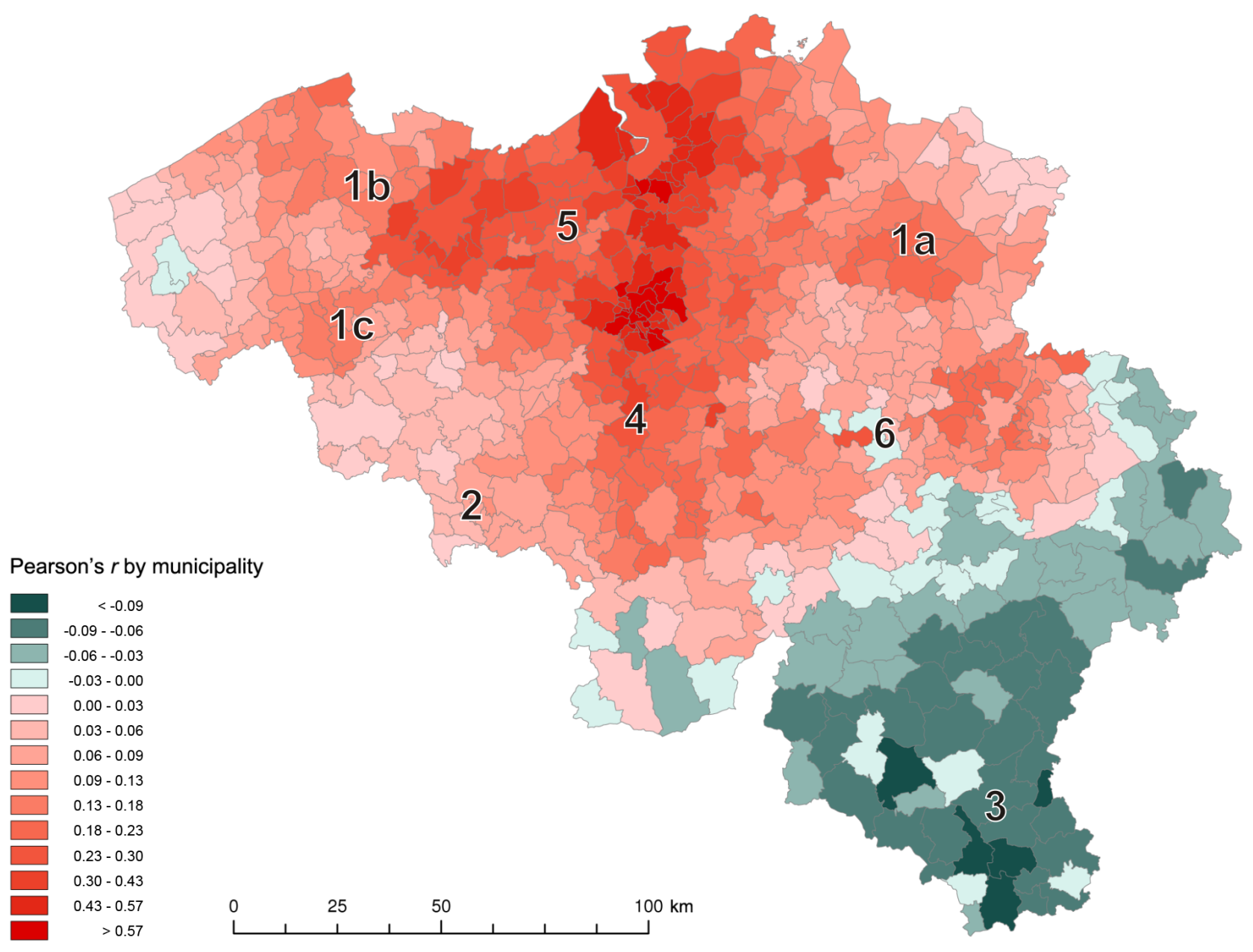

Figure 6.8. The central Belgian metropolitan area: Levels of labor market connectivity 
Figure 6.7 displays a number of important features. Notably, it confirms the dominant position of Brussels in the Belgian labor market. People commute to Brussels from the other municipalities (53.1\% of the jobs located in the Brussels urban agglomeration), but this relation is hardly reciprocated (only $7.3 \%$ of the Brussels agglomeration's population works elsewhere). In the urban agglomerations of Charleroi (28.3\%) and Ghent (29.1\%) a little below one third of the labor force living there works somewhere else (again particularly in the Brussels urban agglomeration). We see that the individual labor markets of the larger urban agglomerations Antwerp (19.6\%) and in particular Liège $(17.0 \%)$ are more self-directed since a substantial smaller fraction of the labor force commutes to elsewhere. As mentioned, the only somewhat reciprocal relationship between urban agglomerations in terms of a balanced polycentric region is between Antwerp and Ghent, although it pales in comparison with the commute to the Brussels urban agglomeration.

In Figure 6.8, the intra-municipal relationships are excluded. This highlights the longer commutes, which tend to positively bias the specialized and higher-educated professions that are important for metropolization (Burger et al., 2014). By applying the intramunicipal filter, the resulting map illuminates the degree of integration between a municipality and all the other municipalities.

Figure 6.8 maps the level of connectivity for each of the Belgian municipalities. Remember that this is a Pearson's correlation between the distribution of the origins of the actual commute towards that municipality and the distribution for the country as a whole. Therefore, the darker the red shade on the map, the more a municipality's travelto-work pattern resembles the average nation-wide travel-to-work pattern. In the cases where the value is close to (light shades) or below (blue shades) zero, this may be interpreted as a sign of dissimilarity (see below). Interestingly, Figure 6.8 provides us with a contiguous topographical representation of a coherent metropolitan region. Comparing Figures 6.6 and 6.8 is insightful: Figure 6.6 shows the spatial distribution of the origins of the incoming commute in Brussels, while Figure 6.8 indicates the extent to which the incoming commute in every Belgian municipality resembles the geographical distribution of the commuter trips departing from all Belgian municipalities. The similarity between the two maps stresses the importance of Brussels as a national employment center, while the differences between the maps indicate that Belgium should not just be seen as the periphery of Brussels.

We will now run through a number of salient features (labeled \#1a through \#6 on Figure 6.8). First, Figure 6.8 renders both the Flemish Diamond (\#5) and the Walloon Triangle (\#4) visible, making them more than policy phantasmagorias. Although weaker in the Walloon Triangle, both regions show integration in labor market patterns. Not only does the metropolitan core area include the municipality of Charleroi and the municipalities directly south of Charleroi, it also extends east and west of Charleroi toward the other vertexes of the Triangle (the cities of Mons and Namur). On a larger scale, the conjunction of the Flemish Diamond and the Walloon Triangle indicates that the old $\mathrm{ABC}$-Axis might be regaining some prominence as the backbone of the Belgian metropolitan area, albeit that the area extends far beyond the $\mathrm{ABC}$-axis. For example, we 
can clearly see some of the linear urbanization patterns that were the hallmark of Belgian Fordism as outward extensions of the Flemish Diamond (\#1a, \#1b and \#1c on Figure 6.8), which all follow major infrastructure axes. Despite being girded on a similar major infrastructure belt, the Walloon Axis still does not extend beyond the base of the Walloon Triangle and retains its fragmentation (\#6). This is exemplified by the position of the Liège agglomeration, the only somewhat isolated region that still contributes enough to the Belgian average commute to achieve prominence, although we note that this is not true for the core municipality of Liège itself, underscoring its self-reliant position. In sum, this investigation indicates that an integrated metropolitan labor market exists. Its shape is hourglass-like with a somewhat weaker Walloon base than the Flemish roof. Note that apart from the infrastructure-heavy Brussels-Charleroi corridor, the language barrier indicates a spatial breach in the labor market system (cf. Verhetsel et al., 2009: 28). However, as the area is relatively thinly populated (Figure 6.1) and tangential infrastructure that evades Brussels is scarce (Figure 6.2), we cannot make definite inferences on the causes of that barrier.

It should be stressed that there is notable diversity in municipalities exposing low correlations, i.e. those who are outside of the central metropolitan area. This could either indicate a somewhat thick but autarchic local labor market, such as the municipality of Liège which is filtered-out by excluding the intra-zonal commute, or rather idle areas in terms of local employment and commuting as in the Luxembourg province. In this respect, it is important to examine some of the areas with high population densities (Figure 6.1) that are nevertheless located outside the integrated region in Figure 6.6. Area \#2 (the Borinage) indeed qualifies as a problem region, having a high population density and an absence of jobs combined with underemployment (cf. Verhetsel et al., 2009: 45). In contrast, the region west of \#1c, the southwest Flanders cluster, has a low average commuting distance, which signals a degree of autarchy (Boussauw et al., 2011) congruent with its industrial district autonomy. Furthermore, the Campine area (north of \#1a) seems relatively weakly connected to the metropolitan core area. This is the branch plant economy that developed in the late-industrial era and has seen signs of deindustrialization lately. Consequently, the average commute is increasing (Boussauw, 2011). Lastly, the negative coefficients in the Belgian Luxembourg province (\#3) catch the eye. Although cross-border commuting is not directly captured by the dataset, these values, which indicate divergent commuting patterns, corroborate claims by other authors (e.g. Vandermotten et al., 2006) that the area is functionally integrated with the nearby city of Luxembourg.

\subsection{Discussion and Conclusion}

Imagine a 'naive' spatial economist, with no prior knowledge about Belgium's history and urban system, set loose on the commuting data on which this study is based. Little doubt $s$ (he) would quickly conclude that the small state of Belgium is in fact an enlarged city state where growth in a higher-tier city, Brussels, spills over in the second tier cities close by and write this up in an elegant parsimonious model. However, as time passes, our spatial economist would increasingly observe aberrations from this model. The spatial 
imaginaries and policies in Flanders and Wallonia consider Brussels the geographic frontier rather than the center and people act accordingly. Thus, Brussels finds itself increasingly unable to enact the policies necessary for its own growth. Additionally, $s($ he) would learn that Belgian people tend to cling to their own homes and their own communities, despite that migrating to Brussels would be by far the more 'rational option'. In other words, there is a huge difference between the outsider perspective of our spatial economist who will see the homogeneity of the nebular city and the insider perspective that sees so much complexity that it sometimes feels that each little droplet of the nebula is a world of its own and fails to envision how things cohere on the Belgian level.

This chapter is an attempt to steer a middle course between these two extremes, highlighting continuities and change by contextualizing the spatial-economic analysis historically. Whether representing actual economic activities on the ground or beig mere policy-informing geographic phantasmagorias, historical urbanization patterns and scales (the Walloon Axis, the ABC-Axis, the Flemish Diamond and the Walloon Triangle) cannot be cast aside. Simultaneously, we have to acknowledge that patterns of urbanization are contingent and have changed form and function over the last centuries. Thus, we have to seriously consider 'metropolization' as a potential emerging agglomeration-economy regime.

To examine the applicability of metropolization, we have studied the inter-urban commuting patterns in the Belgian urban system. The result shows a contiguous geography that can be regarded as a metropolitan core area as far as labor markets are concerned. The description of an hourglass-shaped metropolitan area whose (Walloon) base is less developed than its (Flemish) roof seems an apt geographical metaphor. The weakly developed base fits into the history of deindustrialization of the Walloon Axis, although the analysis confirms that growth spreading out from Brussels is re-integrating parts of this Axis. However, the roof-primarily consisting of the Flemish Diamondplays a role that is a too important to consider metropolization as a mere extension of Brussels. Equally, metropolization is not a simple re-constitution of the ABC-Axis. The observation that that the core area extends outwards from the Flemish Diamond into three corridors underscores the wider relevance of cities other than Brussels.

Our analysis is, like any other, partial. Since we want to understand labor market integration, the study emphasized inter-municipal commute over intra-municipal mobility. Moreover, an analysis of different regionalization indicators yields different geographies, which always interact with one another. Thus, the importance of Brussels for business networks (Vandermotten et al., 2006; Hanssens et al., 2014) will be a centripetal influence on the labor market system described herein, while the relatively local focus of Belgian social networks (Blondel et al. 2010) will likely induce centrifugal urbanization tendencies. Furthermore, when considering the provision of daily amenities, Belgium's spatial structure retains central place system characteristics (Van Hecke, 1998; Boussauw et al., 2014). This multiplicity of urban subsystems and their interactions (Burger et al., 2014) necessitates qualification of the ideal-typical story of hermetic agglomerationeconomy regimes. 
These conclusions bode challenges for Belgian policy-makers for whom centrifugal economic development has for a long time been coupled with centrifugal political reform. The regional governments now responsible for most spatial and economic policy are for the first time confronted with centripetal economic development. Additionally, if the Belgian state wants to profit optimally from the economic benefits that a wellfunctioning metropolitan region may offer, it will be inevitable to address the question of how to provide environmentally, politically and economically sustainable spatial planning for the administratively constrained BCR.

\section{References}

Abu-Lughod JL (1989) Before European Hegemony: The World System A.D. 1250-1350. New York and Oxford: Oxford University Press.

Albrechts L (1998) The Flemish Diamond: Precious gem and virgin area. European Planning Studies 6(4): 411-424.

Albrechts L and Lievois G (2004) The Flemish Diamond: Urban network in the making? European Planning Studies 12(3): 351-370.

Allen J, Massey D and Cochrane A (1998) Rethinking the Region. London and New York: Routledge.

Antrop M (2004) Landscape change and the urbanization process in Europe. Landscape and Urban Planning 67(1-4): 9-26.

Bassens D and van Meeteren M (2015) World cities under conditions of financialized globalization: Towards an augmented world city hypothesis. Progress in Human Geography 39(6): 752-775.

Blondel V, Krings G and Thomas I (2010) Regions and borders of mobile telephony in Belgium and in the Brussels metropolitan zone. Brussels Studies 42(4): 1-12.

Boschma RA (1994) Looking Through a Window of Locational Opportunity. Amsterdam: Thesis Publishers.

Boussauw K (2011) Aspects of Spatial Proximity and Sustainable Travel Behaviour in Flanders: A Quantitative Approach. PhD Thesis. Ghent: Ghent University.

Boussauw K, Allaert G and Witlox F (2013) Colouring inside what lines? Interference of the urban growth boundary and the political-administrative border of Brussels. European Planning Studies 21(10): 1509-1527.

Boussauw K and Boelens L (2015) Fuzzy tales for hard blueprints: The selective coproduction of the Spatial Policy Plan for Flanders, Belgium. Environment and Planning C: Government and Policy 33(6): 1376-1393. 
Boussauw K, Derudder B and Witlox F (2011) Measuring spatial separation processes through the minimum commute: The case of Flanders. European Journal of Transport and Infrastructure Research 11(1): 42-60.

Boussauw K, van Meeteren M and Witlox F (2014) Short trips and central places: The home-school distances in the Flemish primary education system (Belgium). Applied Geography 53: 311-322.

Braudel F (1984) The Perspective of the World. London: William Collins Sons \& Co.

Burger MJ and Meijers EJ (2012) Form follows function? Linking morphological and functional polycentricity. Urban Studies 49(5): 1127-1149.

Burger MJ, van der Knaap B and Wall RS (2014) Polycentricity and the multiplexity of urban networks. European Planning Studies 22(4): 816-840.

Cabus P and Vanhaverbeke W (2003) Ruimtelijk-Economische Dynamiek in Vlaanderen. Ghent: Academia Press.

Champion AG (2001) A changing demographic regime and evolving polycentric urban regions: Consequences for the size, composition and distribution of city populations. Urban Studies 38(4): 657-677.

Corijn E and Vloeberghs E. (2009) Brussel! Brussels: ASP.

Cox KR (2002) "Globalization," the "regulation approach," and the politics of scale. In: Herod A and Wright MW (Eds) Geographies of Power, Placing Scale. Malden: Blackwell Publishing, pp. 85-114.

Cox KR and Mair A (1988) Locality and community in the politics of local economic development. Annals of the Association of American Geographers 78(2): pp. 307325.

David Q, Peeters D, Van Hamme G and Vandermotten C (2013) Is bigger better? Economic performances of European cities, 1960-2009. Cities 35: 237-254.

De Block G and Polasky J (2011) Light railways and the rural-urban continuum: Technology, space and society in late nineteenth-century Belgium. Journal of Historical Geography 37(3): 312-328.

De Decker P (2011) Understanding housing sprawl: The case of Flanders, Belgium. Environment and Planning A 43(7): 1634-1654.

Dehaene M and Loopmans M (2003) Een argeloze transformatie naar een diffuse stad. Agora 19(3): 4-6. 
De Meulder B, Schreurs J, Cock A and Notteboom B. (1999) Patching up the Belgian urban landscape. Oase 52: 79-113.

De Wachter A and Saey P (2005) Trajectories of regions and spatial integration in the world-system. Tijdschrift voor Economische en Sociale Geografie 96(2): 153-167.

Dickinson RE (1957) The geography of commuting: The Netherlands and Belgium. Geographical Review 47(4): 521-538.

Dijkstra L, Garcilazo E and McCann P (2013) The economic performance of European cities and city regions: Myths and realities. European Planning Studies 21(3): 334354.

Friedmann J and Miller J (1965) The urban field. Journal of the American Institute of Planners 31(4): 312-320.

Hall P (1984 [1966]) The World Cities (3rd edn). London: George Weidenfeld \& Nicolson Limited.

Hanssens H, Derudder B, Van Aelst S and Witlox F (2014) Assessing the functional polycentricity of the mega-city-region of Central Belgium based on advanced producer service transaction links. Regional Studies 48(12): 1939-1953.

Harvey D (1996) Cities or urbanization? City: Analysis of Urban Trends, Culture, Theory, Policy, Action 1(1-2): 38-61.

Hohenberg PM and Lees LH (1995 [1985]) The Making of Urban Europe 1000-1994. Cambridge MA and London: Harvard University Press.

Janelle DG (1969) Spatial reorganization: A model and concept. Annals of the Association of American Geographers 59(2): 348-364.

Jessop B and Oosterlynck S (2008) Cultural political economy: On making the cultural turn without falling into soft economic sociology. Geoforum 39: 1155-1169.

Keil R and Ronneberger K (1994) Going up the country: Internationalization and urbanization on Frankfurt's northern fringe. Environment and Planning D: Society and Space 12(2): 137-166.

Kesteloot C and Saey P (2002) Brussels, a truncated metropolis. GeoJournal 58(1): 53-63.

Kipnis BA and Swyngedouw EA (1988) Manufacturing research and development in a peripheral region: The case of Limburg, Belgium. The Professional Geographer 40(2): 149-158. 
Krätke S (2007) Metropolisation of the European economic territory as a consequence of increasing specialisation of urban agglomerations in the knowledge economy. European Planning Studies 15(1): 1-27.

Krätke S (2014) Cities in contemporary capitalism. International Journal of Urban and Regional Research 38(5): 1660-1677.

Limtanakool N, Dijst M and Schwanen T (2007) A theoretical framework and methodology for characterising national urban systems on the basis of flows of people: Empirical evidence for France and Germany. Urban Studies 44(11): 21232145.

Luyten S and Van Hecke E (2007) De Belgische Stadsgewesten 2001. Brussels: Statistics Belgium Working Paper.

Mandel E (1963) The dialectic of class and region in Belgium. New Left Review 20: 5-31.

Massey D (1979) In what sense a regional problem? Regional Studies 13(2): 233-243.

McCann P and Acs ZJ (2011) Globalization: Countries, cities and multinationals. Regional Studies 45(1): 17-32.

McKenzie RD (1968 [1933]). The rise of metropolitan communities. In: Hawley AH (Ed.), Roderick D. McKenzie on Human Ecology. Chicago and London: University of Chicago Press, 244-305.

Meijers EJ, Hoogerbrugge $M$ and Hollander K (2014) Twin cities in the process of metropolisation. Urban Research and Practice 7(1): 35-55.

Mommen A (1994) The Belgian Economy in the Twentieth Century. London and New York: Routledge.

Musyck B (1995) Autonomous industrialization in South West Flanders (Belgium): Continuity and transformation. Regional Studies 29(7): 619-633.

Oosterlynck S (2009) The political economy of state restructuring and the regional uneven transition to after-fordism in Belgium. In: Handelingen van het contactforum "Contemporary Centrifugal Regionalism: Comparing Flanders and Northern Italy", June 19-20 2009, Brussels, pp. 83-93. Available at http://poli.vub.ac.be/publi/online/alles-michel.pdf (accessed October 4, 2015)

Oosterlynck S (2010) Regulating regional uneven development and the politics of reconfiguring Belgian state space. Antipode 42(5): 1151-1179.

Pain K, Van Hamme G, Vinciguerra S and David Q (2015) Global networks, cities and economic performance: Observations from an analysis of cities in Europe and the USA. Urban Studies, DOI: 10.1177/0042098015577303 
Phelps NA and Ozawa T (2003) Contrasts in agglomeration: Proto-industrial, industrial and post-industrial forms compared. Progress in Human Geography 27(5): 583604.

Phelps NA (2004) Clusters, dispersion and the spaces in between: For an economic geography of the banal. Urban Studies 41(5-6): 971-989.

Reid A and Musyck B (2000) Industrial policy in Wallonia: A rupture with the past? European Planning Studies 8(2): 183-200.

Riguelle F, Thomas I and Verhetsel A (2007) Measuring urban polycentrism: A European case study and its implications. Journal of Economic Geography 7(2): 193-215.

Rosenthal SS and Strange WC (2004) Evidence on the nature and sources of agglomeration economies. In: Henderson JV and Thisse J-F (Eds.) Handbook of Regional and Urban Economies, Volume 4. Amsterdam: Elsevier, 2120-2171.

RSV (1997/2004) Ruimtelijk Structuurplan Vlaanderen. Brussels: Vlaamse Overheid. Available at http://rsv.vlaanderen.be (accessed October 4, 2015).

RSZ (2011) Werknemers Onderworpen aan de Sociale Zekerheid naar Plaats van Tewerkstelling: Gegevens op 31 december 2010. Brussel: Rijksdienst voor Sociale Zekerheid. Available at http://www.rsz.fgov.be (accessed October 4, 2015).

Ryckewaert M (2011) Building the Economic Backbone of the Belgian Welfare State. Infrastructure, planning and architecture 1945-1973. Rotterdam: 010 Publishers.

Sassen S (2008) Re-assembling the urban. Urban Geography 29(2): 113-126.

Scott AJ (1982) Locational patterns and dynamics of industrial activity in the modern metropolis. Urban Studies 19(2): 111-141.

Scott AJ (1988a) Metropolis. From the Division of Labor to Urban Form. Berkeley, Los Angeles and London: University of California Press.

Scott AJ (1988b) Flexible production systems and regional development. International Journal of Urban and Regional Research 12(2): 171-186.

Scott AJ (2012) A World in Emergence. Cities and Regions in the 21st Century. Cheltenham: Edward Elgar.

SDER (1998) Schéma de Développement de l'Espace Régional. Namur: Gouvernement Wallon. Available at http://developpement-territorial.wallonie.be (accessed October 4, 2015).

Stewart JQ (1948) Demographic gravitation: Evidence and applications. Sociometry, 11(12):31-58. 
Swyngedouw EA (1990) Limburg en de wereldeconomie: Het Belgische Fordisme op zijn best. In: Werkgroep Mort Subite (Ed.), Barsten in België. Een geografie van de Belgische Maatschappij, Antwerp: EPO, 109-139.

Taylor PJ and Derudder B (2016) World City Network: A Global Urban Analysis, (2nd edn). London and New York: Routledge.

Thisse J-F and Thomas I (2010) Brussels within the Belgian Economy: A geo-economic approach. In: De Grauwe P and Van Parijs P (Eds.) What does Geography teach us about the Future of Belgium's Institutions? Brussels: The University Foundation, 5-19.

Turok I and Mykhnenko V (2007) The trajectories of European cities, 1960-2005. Cities 24(3): 165-182.

Van Criekingen M, Cornut P and Luyten, S (2007) Brussels: Polycentricity as "images on the map," not in reality. In: Cattan N (Ed.) Cities and Networks in Europe. A Critical Approach of Polycentrism Paris: John Libbey Eurotext, pp. 105-112.

Van der Haegen H, Pattyn M and Cardyn C (1982) The Belgian settlement system. In: Van der Haegen $\mathrm{H}$ (ed.) West European Settlement systems.. Acta Geographica Lovaniensia 22. Leuven: Geografisch Instituut Katholieke Universiteit Leuven, 251-365.

Van der Knaap B (1980) Population Growth and Urban Systems Development: A case Study. Dordrecht and Hingham MA: Martinus Nijhoff Publishing.

Van der Laan L and Schalke R (2001) Reality versus policy: The delineation and testing of local labour market and spatial policy areas. European Planning Studies 9(2): 201221.

Van Nuffel N and Saey P (2005) Commuting, hierarchy and networking: The case of Flanders. Tijdschrift voor Economische en Sociale Geografie 96(3): 313-327.

Van Oudheusden M, Charlier N, Rosskamp B and Delvenne P (2015) Flanders Ahead, Wallonia Behind (But Catching Up): Transforming Flanders and Wallonia into Full-fledged Knowledge-Based Economies. Working paper: Université de Liège.

Vandermotten C, Vandewattyne P (1985) Groei en vorming van het stadsstramien in België. Tijdschrift van het Gemeentekrediet 39(154): 41-62.

Vandermotten C (1986) La Wallonie dans la crise. Temps longs et lecture de l'espace economique. Wallonie, Conseil Economique et Social De La Region Wallonie, 13(73): 49-67.

Vandermotten C (1998) Dynamiques spatiales de l'industrialisation et devenir de la Belgique. Le Mouvement Social 185: 75-100. 
Vandermotten C, Leclercq E, Cassiers T and Wayens B (2009) The Brussels Economy. Brussels Studies. Synopsis nr.7.

Vandermotten C, Roelandts M, Aujean L and Castiau E (2006) Central Belgium: Polycentrism in a federal context. In: Hall P and Pain K (Eds.) The Polycentric Metropolis. London: Earthscan, 146-153.

Vandermotten C, Marissal P and Van Hamme G (2010) La Production des Espaces Economiques, Tome II: La Formation des Territoires (2nd edn.) Brussels: Editions de l'Université de Bruxelles.

Vandermotten C, Saey P and Kesteloot C (1990) België in stukken: Bestaan Vlaanderen en Wallonië echt? In: Werkgroep Mort Subite (Ed.) Barsten in België. Een geografie van de Belgische Maatschappij, Antwerpen: EPO, 11-65.

Van Meeteren M, Poorthuis A, Derudder B and Witlox F (2015) Pacifying Babel's Tower: A scientometric analysis of polycentricity in urban research, Urban Studies DOI: $10.1177 / 0042098015573455$

Van Hecke E (1998) Actualisering van de stedelijke hiërarchie in België. Tijdschrift van het Gemeentekrediet 52(20): 45-76.

Vanhaverbeke W (1998) An economic analysis of the Flemish Diamond, European Planning Studies 6(4): 425-442.

Vanneste D (1985) Site en situatie van de Belgische steden. Tijdschrift van het Gemeentekrediet 39(154): 21-40.

Vasanen A (2012) Functional polycentricity: Examining metropolitan spatial structure through the connectivity of urban sub-centres. Urban Studies 49(16): 3627-3644.

Vasanen A (2013) Spatial integration and functional balance in polycentric urban systems: A multi-scalar approach. Tijdschrift voor Economische en Sociale Geografie 104(4): 410-425.

Verhetsel A, Van Hecke E, Thomas I, et al. (2009) Pendel in België. Brussels: Statbel.

Witte E, Craeybeckx J and Meynen A (2005) Politieke Geschiedenis van België van 1830 tot heden, (7th edn). Antwerp: Standaard Uitgeverij. 